\title{
Antibodies with the Cell-type Specificity to the Morula Cells of the Solitary Ascidians Styela Rustica and Boltenia Echinata
}

\author{
Olga I. Podgornaya ${ }^{1}$ and Tatjana G. Shaposhnikova ${ }^{2, *}$ \\ ${ }^{1}$ Institute of Cytology RAS, Tihoretsky pr, 4; 194064, St. Petersburg, Russia and ${ }^{2}$ Department of Cytology and \\ Histology, Faculty of Biology and Soil sciences, St. Petersburg State University, Universitetskaja nab. 7/9, St. \\ Petersburg, 199034 Russia
}

Key words: ascidians/phenoloxidase system/morula cells/antibodies

\begin{abstract}
The separation of the blood cells of Styela rustica (Styelidae, Stolidobranchiae) in discontinuous Percoll gradient showed 4 fractions. The 4th and bottom most fraction contained 90-100\% of morula cells. The protein composition of the morula cell fraction revealed on SDS-PAGE showed two major proteins with m.w. 47 and $26 \mathrm{kDa}$. These proteins were heavily positively charged. Polyclonal antiserums against these proteins were raised. Each antiserum reacted with both proteins only in morula cells on the blot after SDS-PAGE and stained the proper protein without crossreaction on the blot after AU-PAGE. The only type of cells stained with antibodies in circulating blood, in the tunic and on the tunic wound surface in paraffin sections of another species Boltenia echinata (Pyuridae, Stolidobranchiae) were morula cells. The morula-type specific antibodies obtained recognized major positively charged proteins which were apparently structural substrates for the phenoloxidase tanning.
\end{abstract}

The origin of defense and recognition systems in invertebrate and vertebrate animals is the subject of comparative immunology. Particular attention should be paid to ascidians because of their unique phylogenetic position. One of the main defense and/or recognition systems of many groups of invertebrates is the phenoloxidase system (PO system) $(30,31)$. Ascidians use the PO system not only for defense reactions but for the sclerotization of proteins in tunic $(2,4,5,9,12,20,28)$. This system in ascidians is localized in the morula cells which seems to be a characteristic type for ascidians of all three families of the order Stolidobranchia $(8,10,16$, $17,35)$. Granules of morula cells contain components of the PO system: PO in inactive form, binding metals (iron or vanadium), polyphenolic compounds, cationic proteins $(1,4,7,11,14,20,22,29,33)$. The morula cells are thus one of the key points of the defense system of ascidians.

Phase contrast microscopy, Nomarsky optics and histological analysis of differentially stained sections

* To whom reprint requests should be addressed.

E-mail: shapa@histo.bio.pu.ru

Abbreviations: SDS-PAGE, SDS polyacrylamide gel electrophoresis; AU-PAGE, acid-urea polyacrylamide gel electrophoresis; PBSTw, phosphate-buffered saline with $0.05 \%$ Tween 20; AB26, antiserum against $26 \mathrm{kDa}$ protein; $\mathrm{AB} 47$, antiserum against $47 \mathrm{kDa}$ protein; PO system, phenoloxidase system; m.w., molecular weight; ASW, artificial sea water; CBB, Coomassie Brilliant Blue; BCIPNBT, 5-bromo-4-chloro-3-indolyl phosphate-nitroblue tetrazolium. identified 12 types of cells in the blood of solitary ascidian Styela rustica (10). The main types of blood cells were the following: haemocytoblasts, hyaline amebocytes, granulocytes, macrophages, and morula cells vacuolated, young, intermediate and mature. The average number of blood cells in circulation was $10.8 \pm 6.1$ $\mathrm{mln} / \mathrm{ml}$, including $35-45 \%$ of morula cells. The signet ring and compartment cells, typical for the other ascidian species, are lacking in S. rustica. Vacuolated, young, intermediate and mature morula cells are presumably the consequent stages of the morula cell differentiation pathway (10). The main part of the mature morula cell population can be considered as cells having terminal differentiation and resting defensive cells. They also migrate into the tunic. According to cytochemical studies, mature morula cells contain the main components of the PO system $(10,11)$.

The goal of the present work was to find out any characteristic components accumulating in this type of cell and to provide antiserums against them as tools for further investigation. We have found two proteins of m.w. $47 \mathrm{kDa}$ and $26 \mathrm{kDa}$ with common antigenic determinants in morula cells of two ascidian species.

\section{MATERIALS AND METHODS}

\section{Animals}

Specimens of Styela rustica were collected at the Marine Biological Station of St. Petersburg State University in Chupa in- 
let of the Kandalaksha bay of the White Sea, and kept in sea water changed twice a day $\left(25 \%, 10^{\circ} \mathrm{C}\right)$. Before bleeding the tunic was cleaned of epiphytes and washed extensively with sea water, dried by blotting with absorbent wipes. The sampling area was sterilized with $70 \%$ ethanol and the body wall was cut to muscular level without injuring the internal organs. The hemolymph exuding from the animal was collected by pipetting into ice-cold tubes rinsed with artificial sea water (ASW) without $\mathrm{Ca}^{2+}$. The composition of ASW was as follows: $0.3 \mathrm{M} \mathrm{NaCl}, 20 \mathrm{mM} \mathrm{KCl}, 15 \mathrm{mM}$ EDTA, $10-50 \mathrm{mM}$ Tris- $\mathrm{HCl} \mathrm{pH} 7.6$.

Boltenia echinata was collected in the same place and used for the experiments with tunic reparation. The animals' tunic was cut to half of tunic depth and after 5 days it was fixed in Bouin solution (27). Paraffin sections were prepared and processed for $\mathrm{AB}$ staining.

\section{Cell Separation}

Percoll solution (Pharmacia, Sweden) was mixed with appropriate volumes of ASW to final concentrations of $65 \%, 50 \%$, $40 \%$, and $30 \%$. Two $\mathrm{ml}$ of each solution were overlaid sequentially into glass centrifuge tubes. Two $\mathrm{ml}$ of hemolymph were layered onto the gradient and the tube was centrifuged in a swing-out rotor at $800 \mathrm{~g}$ for $10 \mathrm{~min}$. Cell layers were collected by gentle aspiration and washed twice in ASW. Bands were numbered from top to bottom of tube. Cell viability and composition of cell fractions were estimated by phase-contrast microscopy. All operations were carried out at $10^{\circ} \mathrm{C}$.

\section{Electrophoresis and western-blot}

Protein composition of the fractions was determined with SDS-polyacrylamide gel electrophoresis (SDS-PAGE) (21). Acid-urea PAGE (AU-PAGE) (24) was performed for the determination of cationic proteins in morula cells. Total histones from rat liver nuclei were used as a marker (a gift from Prof. V.I. Vorobjev, Institute of Cytology, Russian Academy of Sciences). All gels were stained with Coomassie Brilliant Blue (CBB). Electroblotting was done in Laemmli electrode buffer with $20 \%$ methanol (34). The blots were washed with phosphate-buffered solution (PBS) with $0.05 \%$ Tween 20 (PBSTw). This basic solution was used for all antibody work. The blots were blocked with $3 \%$ skimmed milk for periods from 1 hour to overnight (at $4^{\circ} \mathrm{C}$ in the latter case). After that the blots were incubated with rabbit antiserum (working dilution $1: 1,000$ ) for $1 \mathrm{~h}$, washed with PBSTw thrice for $15 \mathrm{~min}$ each time, incubated with alkaline phosphataseconjugated goat anti-rabbit Immunoglobulins (Sigma) and stained with 5-bromo-4-chloro-3-indolyl phosphate and nitroblue tetrazolium (BCIP-NBT) (Sigma) for around $20 \mathrm{~min}$. All operations were performed at room temperature.

\section{Peptide mapping}

Peptide mapping was carried out according to the method of Cleveland et al. (13) as modified by Bandman et al. (6). The proteins in the gel segments - $43 \mathrm{kDa}$ and $47 \mathrm{kDa}$ proteins of
S. rustica morula cells and rabbit actin (a gift from Dr. O. Antropova, Institute of Cytology, Russian Academy of Sciences) - were digested for $30 \mathrm{~min}$ with $5 \mu \mathrm{l}$ of Staphylococcus aureus V8 protease (type XVII B, Sigma: P-2922) solution at the following concentrations: $0.2 \mu \mathrm{g} / \mathrm{ml} ; 1 \mu \mathrm{g} / \mathrm{ml} ; 5$ $\mu \mathrm{g} / \mathrm{ml} ; 10 \mu \mathrm{g} / \mathrm{ml}$ in reducing buffer for SDS-PAGE. The control contained no protease. Proteolytic fragments were separated on $15 \%$ gel and stained with $\mathrm{CBB}$.

\section{Antibody production}

Two polyclonal antibodies against two major proteins of morula cells were obtained. In this paper they will be named antiserum against $26 \mathrm{kDa}$ protein (AB26) and antiserum against $47 \mathrm{kDa}$ protein (AB47). The immunization procedure included the following steps. Proteins of the morula cell fraction were separated by SDS-PAGE. The $26 \mathrm{kDa}$ and $47 \mathrm{kDa}$ proteins were cut out from the slab gel, homogenized with PBS and mixed with Freund adjuvant (1:1); this mixture was injected hypodermically into two male rabbits. Boosting with the same mixture was performed intramuscularly in 4 weeks. A week later about $5 \mathrm{ml}$ of blood was taken from the rabbits' ear. The antiserums were aliquoted and stored at $-20^{\circ} \mathrm{C}$. The samples of pre-immune serums were obtained from the same rabbits a week before antigen injection for control staining.

\section{Immunohistochemistry}

Adult individuals of Styela rustica and Boltenia echinata were fixed in Bouin solution for 24 hours and then rinsed in $70^{\circ}$ ethanol. Fixed samples were embedded in paraffin and sectioned at 5-7 $\mu \mathrm{m}$. The traces of picric acid were washed out with $70^{\circ}$ ethanol after removal of paraffin, and then these sections were washed with PBSTw. Immunohistochemical staining basically followed the procedure described in chapter "Electrophoresis and western blot". All operations were performed in a moist chamber at room temperature. The stained sections were mounted in $80 \%$ glycerol. For control some sections were incubated with pre-immune rabbit serum with all the sequential steps. Preparations were observed under a light microscope.

\section{RESULTS}

\section{Resolution of the gradient}

The cells washed out of the Percoll gradient solution were alive and motile. The bottom (4th) fraction had the most stable composition; no less that $90 \%$ and often up to $100 \%$ of the cells were mature morula cells. SDSPAGE of all fractions and plasma proteins is presented in the Fig. 1. There are about 10 proteins in cellfree plasma. The protein of $23 \mathrm{kDa}$ is the main one. A protein of very high mol.mass is also visible among plasma proteins. All cell fractions contained 4 zones in the range of $16-19 \mathrm{kDa}$ which probably correspond to the histones as judged by their apparent mobility in 


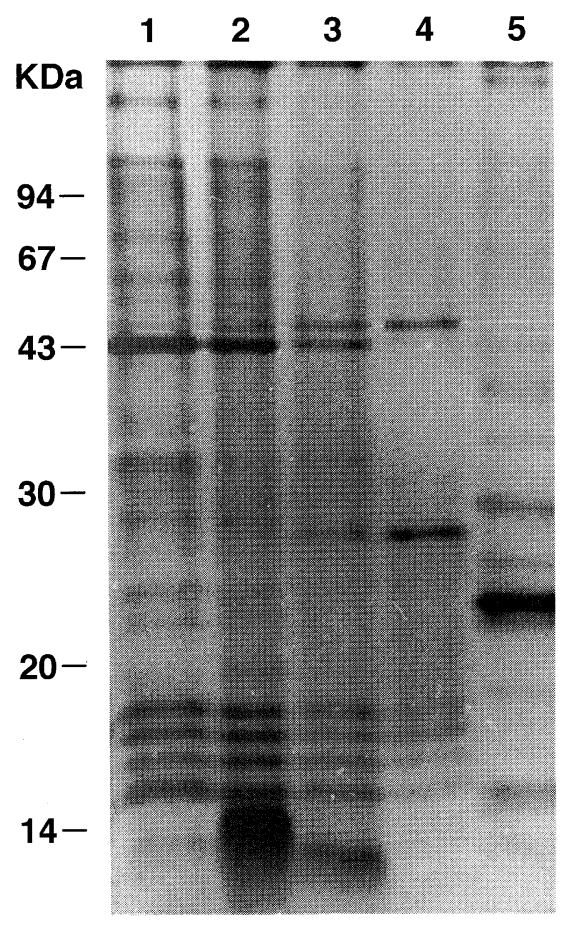

Fig. 1. SDS-PAGE of proteins separated by Percoll discontinuous gradient. $26 \mathrm{kD}$ and $47 \mathrm{kD}$ proteins are the major ones in the 4 th fraction (mature morula cells). 12\% gel. Lane 1: fraction 1; lane 2: fraction 2; lane 3: fraction 3; lane 4: fraction 4; lane 5: plasma.

SDS-PAGE $(21,24)$. These zones are practically absent from the plasma fraction and vice versa - plasma proteins are absent from the cell fractions. This is evidence that there is no cross-contamination of plasma and cell fractions and no cell lysis occurs during separation.

The protein compositions of the two top fractions revealed large amounts of protein with mol.mass $43 \mathrm{kDa}$. The 4th fraction which consisted of mature morula cells displayed 2 major proteins of mol.mass 47 and $26 \mathrm{kDa}$ in similar amounts (Fig. 1, 4). The previous fraction with younger morula cells also contained these proteins as major ones, but in this case the amount of the $47 \mathrm{kDa}$ protein is higher than that of the $26 \mathrm{kDa}$ one and a $43 \mathrm{kDa}$ zone is visible (Fig. 1, 3).

\section{Peptide mapping}

A high content of filamentous actin is a characteristic feature of hyaline amebocytes - cells with a high motility (10). The $47 \mathrm{kDa}$ protein seems to be typical for the morula cells; the mol.mass similarity suggests that this protein could be an ascidian isoform of actin with unusual electrophoretic mobility. In order to examine this possibility we did comparative peptide mapping of the rabbit stress muscle actin, the $43 \mathrm{kDa}$ protein from the cell fractions from the top of the gradient and the 47

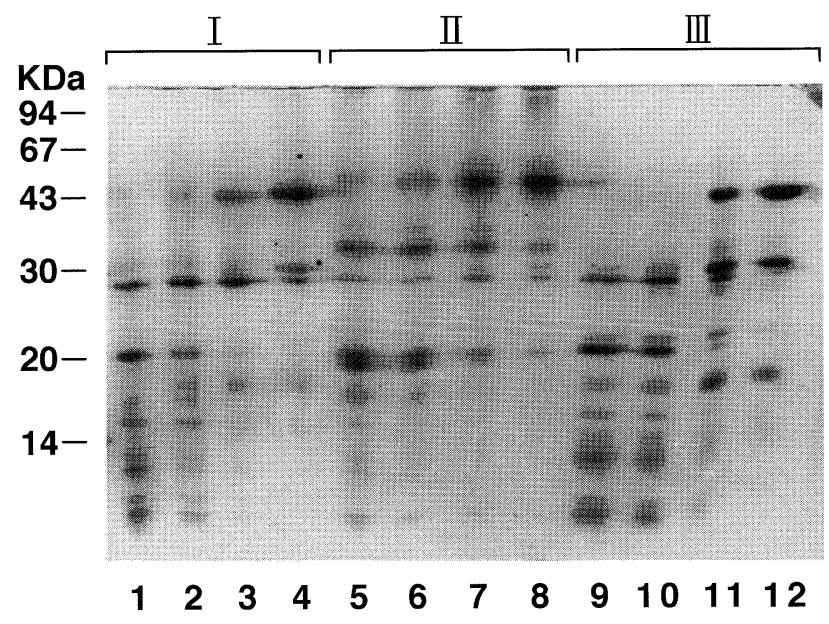

Fig. 2. Peptide mapping of $43 \mathrm{kD}$ (I), $47 \mathrm{kD}$ (II) proteins of Styela rustica hemocytes and rabbit actin (III). Proteins were digested during $30 \mathrm{~min}$ by Staphylococcus aureus protease V8 in concentrations: Lanes 1, 5, $9-10.0 \mu \mathrm{g} / \mathrm{ml}$; lanes 2, 6, $10-5.0 \mu \mathrm{g} / \mathrm{ml}$; lanes 3, 7, 11 $-1.0 \mu \mathrm{g} / \mathrm{ml}$; lanes $4,8,12-0.2 \mu \mathrm{g} / \mathrm{ml}$. 15\% SDS-PAGE.

$\mathrm{kDa}$ protein from the morula cell fraction. The result is shown in Fig. 2. The pattern of rabbit actin peptides and $43 \mathrm{kDa}$ one of $S$. rustica definitely have features in common so it can be concluded that this is the same protein - actin. The peptide pattern of the $47 \mathrm{kDa}$ protein is rather different from the actins from either species.

\section{Antibodies}

In order to determine whether the $47 \mathrm{kDa}$ and $26 \mathrm{kDa}$ proteins are really characteristic of morula cells we raised polyclonal antibodies against corresponding zones cut out from SDS-PAGE. Western-blot after SDS-PAGE with the ABs obtained showed that both ABs recognize both proteins among morula cells proteins and do not react with proteins of the 1st gradient fraction in 1:1,000 dilution of antiserums. The AB26 affinity is slightly lower than the AB47 one (Fig. 3).

\section{The charge of the major morula cell proteins}

It has been shown that morula cell granules contain cationic proteins enriched by $\varepsilon$-Lysine' aminogroups (11). To check if the major morula cell proteins are charged AU-PAGE sensitive to the positively charged proteins was applied to the cell lysate. AU-PAGE analysis showed several proteins (Fig. 4A). There are two major bands, the higher of which is double, which are localized in the upper part of the gel. The other group of proteins seems to correspond to histones. Histones have been used as markers in AU-PAGE and this group of $S$. rustica proteins has the same mobility.

Immunoblotting has been done with the proteins after AU-PAGE separation (Fig. 4B) and the two ma- 


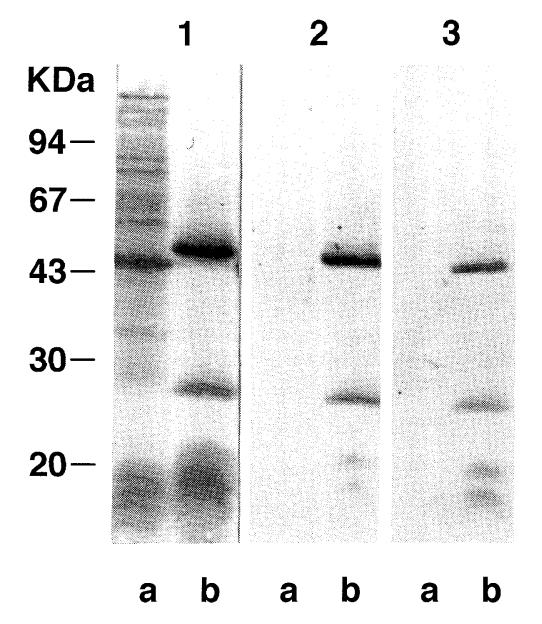

Fig. 3. Western blot of the proteins from morula cell fraction and cells from the 1st gradient fraction with amidoblack 10B (1), antiserums $\mathrm{AB} 26$ (2) and $\mathrm{AB} 47$ (3) in staining dilution 1:1,000. Lane a: proteins of the 1st fraction blood cells; lane b: morula cell proteins of the cells from the 3rd and 4th fractions sampled together. 12\% SDSPAGE.

A

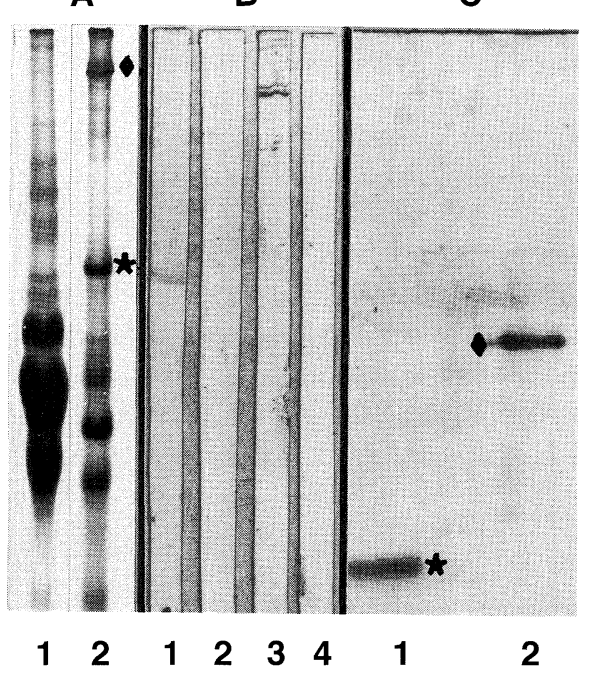

Fig. 4. Determination of cationic properties of morula cell proteins. A: Two main proteins in the morula cells lysate loaded on AUPAGE marked with ${ }^{*}$ and $*(A, 2)$. Total rat histone preparation used as a marker (A, 1). 15\% gel. B: Western blot with the morula cell lysate after AU-PAGE with: lane 1, AB26; lane 3, AB47; lanes 2, 4, pre-immune serums. C: SDS-PAGE of the proteins * (lane 1, $26 \mathrm{kDa}$ ) and (lane 2, $47 \mathrm{kDa}$ ) cut out from AU-PAGE. 12\% gel.

jor bands from AU-PAGE were also cut out from the gel, poured with Laemmli reducing buffer and SDSPAGE was performed (Fig. 4C). The second dimension shows that the upper double band corresponds to the $47 \mathrm{kDa}$ protein and the lower band to the $26 \mathrm{kDa}$ one. In blotting analysis after AU-PAGE both bands

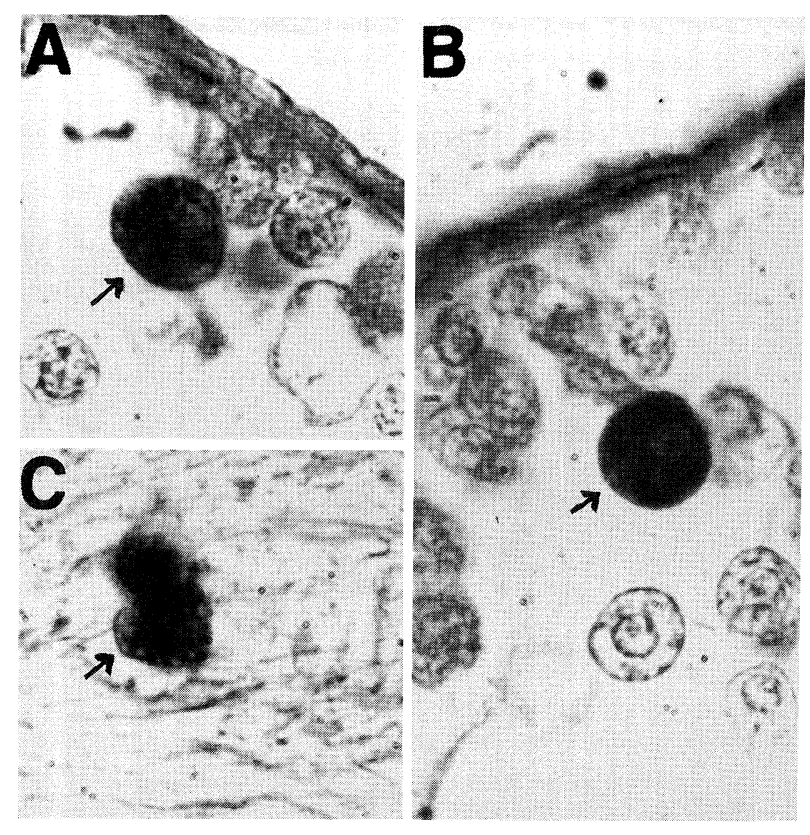

Fig. 5. Immunohistochemical staining of sections of body cavity (A, B) and tunic (C) with AB47 (A, C) and AB26 (B). (A, B) Morula cells are only stained in body cavity (arrows), (C) morula cell in tunic is stained, but the tunic itself is not stained. Magnification: $\times 1,250$.

got stained. AB47 stained the double band which corresponds to the $47 \mathrm{kDa}$ protein, AB26 stained the second band which corresponds to the $26 \mathrm{kDa}$ protein. AB47 affinity is significantly higher. There is no crossreactivity between $\mathrm{ABs}$ in this case.

\section{Immunohistochemistry}

We stained paraffin sections of two ascidian species which belong to the same order but different families that were at our disposal - Styela rustica and Boltenia echinata.

Styela rustica paraffin sections did not get stained with the ABs. In paraffin sections of B. echinata both ABs stained cells in the body cavity and in the tunic. The morphological characteristics of the stained cells (cellular size and shape, and granular size) testify to the fact that it is the morula cells that really get stained (Fig. 5).

To clarify cell-type specificity in staining the following experiment was done. A wounded B. echinata in the process of healing was fixed and the sections were stained with ABs. The staining with AB26 (Fig. 6) and with AB47 (data is not shown) were basically the same. The adjacent sections were treated with immune (Fig. 6A) and pre-immune (Fig. 6B) serums. Pre-immune serum did not give any staining at all. The immune antiserum with AB26 reacted with cells in the body cavity, tunic and on the wound surface (Fig. 6). The localiza- 


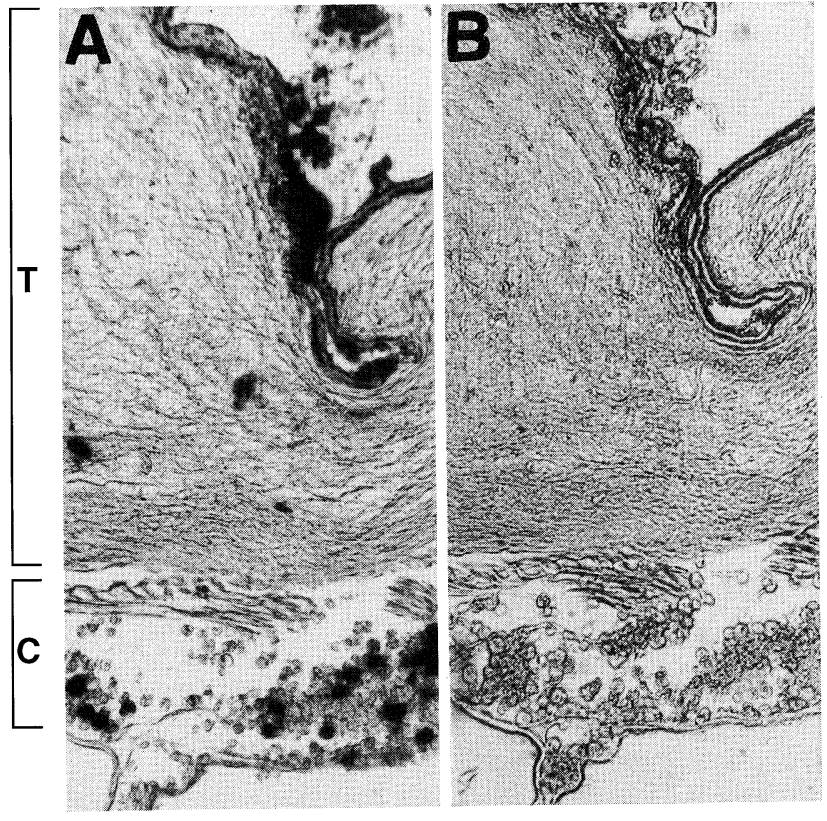

Fig. 6. Immunohistochemical staining of sections of Boltenia echinata body cavity and wounded tunic at 5 days after wounding. Morula cells in body cavity, in tunic and on the wound surface are stained with AB26 (A) but not stained with pre-immune serum (B). (T) Tunic area; (C) body cavity area. Magnification: $\times 250$.

tion of the stained cells corresponded to the expected localization of the morula cells.

\section{DISCUSSION}

Styela rustica blood does not coagulate, unlike insect and crustucean haemolymph $(10,26,32)$. The haemocytes easily agglutinate in sea water but the addition of EDTA to ASW solution prevents cells from aggregating. Similar conditions for separation of ascidian blood cells were used by other investigators $(23,25,30)$.

The Percoll density gradient used in this work had high resolution. Fraction 4 (65\% Percoll, density 1.089 $\mathrm{g} / \mathrm{ml}$ ) contained up to $100 \%$ of morula cells. Such a degree of purity makes it possible to define the main cellspecific proteins. Thus we succeeded in finding two major proteins of $S$. rustica morula cells. These proteins are most likely the components of the PO system which morula cells bear.

One of the components of the PO system is an odiphenol substrate for PO. Several low m.w. polypeptides $(3-10 \mathrm{kDa})$ are described as o-diphenol compounds among ascidians: tunichromes, ferreascidin, halocyamin and others, all of which produce quinones upon enzyme oxidation $(4,14,20,33)$. They are unlikely to have anything in common with the proteins observed because of the striking difference in their mol.masses.
Unfortunately we could not determine the protein nature in the main bands after SDS-PAGE electrophoresis according to the usual functional tests for enzyme activity. The reported mol.mass of the proPO and PO subunits of species from different phylum according to SDS-PAGE lay in the range of $40-200 \mathrm{kDa}(18,19,31)$, hence the $47 \mathrm{kDa}$ protein could be PO or proPO itself. The large positive charge which is shown in the present work makes the $47 \mathrm{kDa}$ and $26 \mathrm{kDa}$ proteins candidates for cationic proteins, the third component of the PO system. According to the cytochemical date the morula cell proteins of $S$. rustica contain a high amount of free lysine $\varepsilon$-aminogroups; this feature gives them a high positive charge and makes them a suitable substrate for the PO system (11).

Our data suggest that despite the crossreactivity of the AB47 and AB26 on the blots after SDS-PAGE electrophoresis, the $26 \mathrm{kDa}$ and $47 \mathrm{kDa}$ proteins are in more complicated connection than a mere dimerization. Protein composition of the cells from gradient fraction 3 - young morula cells - displays higher amounts of the $47 \mathrm{kDa}$ than the $26 \mathrm{kDa}$ protein. In fraction 4 (mature morula cells) both proteins are represented nearly equally (Fig. 1, 4; Fig. 4A). Both have common antigenic determinants after SDS-PAGE (Fig. 3 ). These data allow us to suggest that the $26 \mathrm{kDa}$ could be a derivative of the $47 \mathrm{kDa}$ protein. On the other hand, different antigenic determinants exist in the proteins and are recognized by the correspondent ABs when exposed. This happens after AU-PAGE when crossreactivity of the ABs is not revealed and the specificity of the $A B s$ to each protein increases. Different antigenic determinants are thus exposed after SDS and acid-urea processing. Probably the fixation with urea will also help to increase the specificity of staining on paraffin sections.

The failure of staining of $S$. rustica sections (unlike B. echinata) by conventional procedure may be due to the type of packing of these proteins in morula cell granules which masks the antigenic determinants. There is also no staining in S. rustica and B. echinata extracellular components of the tunic evidently because of the strong tanning of the proteins in it.

Morula cells in tunic release the content of their granules during tunic formation and regeneration. $\mathrm{O}-$ diphenol compounds, oxidized by the PO system, take part in crosslinking of protein substrate and thus tan the upper layer of tunic $(9,15,28)$. They also participate in self/nonself recognition reactions; in all biological reactions involving morula cells the latter form an extracellular matrix consisting of proteins stabilized by the PO system $(2,5,9,12)$. The main proteins of the morula cells observed in this work may be precursors of the proteins tanned by phenols during PO reaction. Protein sequencing of the proteins could give the exact 
answer. Nevertheless, biochemical and immunohistochemical data give evidence that the $47 \mathrm{kDa}$ and $26 \mathrm{kDa}$ proteins are markers of the morula cells since $\mathrm{ABs}$ against these proteins stain only this type of cell. We already know that $\mathrm{ABs}$ work in cell-type specific manner in two ascidian species. The possible limits of applying ABs to the other species remains to be defined. ABs obtained present a useful tool for the investigation of the PO system in defense reactions, in self/nonself recognition reactions, and in the organization of extracellular matrix proteins in tunic formation of such an evolutionary significant species as ascidians.

Acknowledgements. We are grateful to Dr. Oleg Chaga for the initiation of this work, and Dr. Olga Antropova for assistance with some methods. The work was financially supported in part by a grant from the Russian Foundation for Basic Research (code of the project N 9504-12334).

\section{REFERENCES}

1. Agudelo, M.I., Kustin, K., Mcleod, G.C., Robinson, W.E., and WANG, R.T. 1983. Iron accumulation in tunicate blood cells. I. Distribution and oxidation state of iron in the blood of Boltenia ovifera, Styela clava, and Molgula manhattensis. Biol. Bull., 165: 100-109.

2. Akita, N. and Hoshi, M. 1995. Hemocytes release phenoloxidase upon contact reaction, an allogeneic interaction, in the ascidian Halocynthia roretzi. Cell Struct. Funct., 20: 81-87.

3. Arizza, V., Cammarata, M., Tomasino, M.C., and PARRINello, N. 1995. Phenoloxidase characterization in vacuolar hemocytes from the solitary ascidian Styela plicata. J. Invertebr. Pathol., 66: 297-302.

4. AzUmi, K., Yokosawa, H., and IshII, S. 1990. Halocyamins: novel antimicrobial tetrapeptide-like substances isolated from the hemocytes of the solitary ascidian Halocynthia roretzi. Biochemistry, 29: 159-165.

5. Ballarin, L., Cima, F., and Sabbadin, A. 1994. Phenoloxidase in the colonial ascidian Botryllus schlosseri (Urochordata: Ascidiacea). Anim. Biol., 3: 41-48.

6. Bandman, E., Matsuda, R., and Strohman, R.C. 1982. Myosin heavy chains from two different adult fast-twitch muscles have different peptide maps but identical mRNAs. Cell, 92: 645650 .

7. Bayer, E., Schiefer, G., Waidelich, D., ScipPa, S., and DE VICENTIIs, M. 1992. Structure of the tunichrome of tunicates and its role in concentrating vanadium. Angew. Chem. Int. Ed. Engl., 31: 52-54.

8. ChaGa, O.Y. 1980a. Morphology and histochemistry of blood cells of ascidian Molgula citrina. Tsytologia, 22: 287-295.

9. CHAGA, O.Y. 1980b. O-diphenoloxidase system of ascidians. Tsytologia, 22: 619-622.

10. Chaga, O.Y. 1998a. Blood cells of the ascidian Styela (Goniocarpa) rustica. I. Histological study. Tsytologia, 40: 31-44.

11. ChaGA, O.Y. 1998b. Blood cells of the ascidian Styela (Goniocarpa) rustica. II. Cytochemical study. Tsytologia, 40: 45-57.

12. Chaga, O.Y. and Solovey, I.V. 1986. Cuticular epitheliums and granular amoebocytes. Tsytologia, 28: 254-270.

13. Cleveland, D.W., Fischer, S.G., Kirschner, M.W., and LAEMMLI, U.K. 1977. Peptide mapping by limited proteolysis in sodium dodecyl sulfate and analysis by gel electrophoresis. $J$. Biol. Chem., 252: 1102-1106.

14. Dorsett, L.C., Hawkins, C.J., Grice, J.A., Lavin, M.F., Merefield, P.M., PARry, D.L., and Ross, I.L. 1987. Ferreascidin: a highly aromatic protein containing 3,4-dihydroxiphenylalanine from the blood cells of a stolidobranch ascidian. Biochemistry, 26: 8078-8082.

15. EndeAn, R. 1955. Studies of the blood and test of some Australian ascidians. I. Blood of Pyura stolonifera (Heller). Austr. J. Mar. Freshwater Res., 6: 35-59.

16. Fuke, M. and Fukumoto, M. 1993. Correlative find structural, behavioral, and histochemical analysis of ascidian blood cells. Acta Zool., 74: 61-71.

17. Goodbody, I. 1974. The physiology of ascidians. Adv. Mar. Biol., 12: 2-149.

18. Hall, M., Scott, T., Sugumaran, M., Soderhall, K., and LAw, J.H. 1995. Proenzyme of Manduca sexta phenol oxidase: Purification, activation, substrate specificity of the active enzyme, and molecular cloning. Proc. Natl. Acad. Sci. USA, 92: 7764-7768.

19. Johansson, M.W. and Soderhall, K. 1996. The prophenoloxidase activating system and associated proteins in invertebrates. Prog. Mol. Subcell. Biol., 15: 46-66.

20. Kustin, K., Robinson, W.E., and Smith, M.J. 1990. Tunichromes, vanadium, and vacuolated blood cells in tunicates. Invert. Reprod. Dev., 17: 129-139.

21. LAEMMI, U.K. 1970. Cleavage of structural protein during the assembly of the head of the bacteriophage T4. Nature, 4: 680682 .

22. Michibata, H. 1989. New aspects of accumulation and reduction of vanadium ions in ascidians, based on concerted investigation from both a chemical and biological viewpoint. Zool. Sci., 6: 639-647.

23. Michibata, H., Iwata, Y., and Hirata, J. 1991. Isolation of highly acidic and vanadium-containing blood cells from among several types of blood cell from Ascidiidae species by densitygradient centrifugation. J. Exp. Zool., 257: 306-313.

24. Panyrm, S. and Chalckley, R. 1969. High resolution acrylamide gel electrophoresis of histones. Arch. Biochem. Biophys., 130: 337-346.

25. Parrinello, N. and Cammarata, M. 1995. Collection, separation, identification and phagocytic activity of tunicate hemocytes. In Techniques in Fish Immunology-4 (J.S. Stolen, T.C. Fletcher, S.A. Smith, J.T. Zelikoff, S.L. Kaattari, R.S. Anderson, K. Soderhall, and B.A. Weeks-Perkins, eds.). SOS Publications, Fair Haven, NJ, USA.

26. Ratcliffe, N.A., Rowley, S.W., Fitzerald, S.W., and RHODES, C.P. 1985. Invertebrate immunity: basic concepts and recent advances. International review of cytology, 97: 184-350.

27. RomeIs, B. 1953. Microscopic technique. Publishing House of Foreign Literature, Moscow. 718pp.

28. SмIтH, M.J. 1970. The blood cells and tunic of the ascidian Halocynthia aurantium (Pallas). II. Histochemistry of blood cells and tunic. Biol. Bull., 138: 379-388.

29. Sмith, V.J. and Soderhall, K. 1991. A comparison of phenoloxidase activity in the blood of marine invertebrates. Dev. Comp. Immunol., 15: 251-261.

30. Smith, V.J. and Peddie, C.M. 1992. Cell cooperation during host defence in the solitary tinicate Ciona intestinalis (L). Biol. Bull., 183: 211-219.

31. Sмiтн, V.J. 1996. The prophenoloxidase activating system: a common defence pathway for deuterostomes and protostomes? Adv. Comp. Environm. Physiol., 23: 75-114. 
32. Soderhall, K. and Smith, V.J. 1983. Separation of the haemocyte populations of Carcinus maenas and other marine decapods, and prophenoloxidase distribution. Dev. Comp. Immunol., 7: 229-239.

33. TAYlor, S.W., Ross, M.M., and WaIte, J.H. 1995. Novel 3,4di- and 3,4,5-trihydroxiphenylalanine-containing polypeptides from the blood cells of the ascidians Ascidia ceratodes and Molgula manhattensis. Arch. Biochem. Biophys., 324: 228-240.
34. Towbin, H., Staechelin, T., and Gordon, J. 1979. Electrophoretic transfer of proteins from polyacrylamide gel to nitrocellulose sheets: procedure and some applications. Proc. Natl. Acad. Sci. USA, 76: 4350-4354.

35. WRIGHT, R.K. 1981. Urochordates. In Invertebrate blood cells. Academic Press, London, pp565-626.

(Received for publication, June 26, 1998

and in revised form, October 8,1998 ) 